\title{
Impact Of Government Policy and Rationality of the Smoker to the Cigarette Consumption in Indonesia
}

\author{
Noor Syaifudin \\ - UWA Business School, Business School building, Crawley Campus, Perth, Australia \\ - Fiscal Policy Agency, Ministry of Finance of the Republic of Indonesia
}

\begin{abstract}
Even though there is high need of the excise revenue from a cigarette, but the government of Indonesia needs to take into account the long run effect of cigarette to the people. There are poverty, health and education issues relating to the cigarette consumption. Therefore, the government intervention can help people to curb the cigarette consumption. This study attempts to find the impact of the government policy through the excise tariff policy, and the rationality of the smoker to the cigarette consumption in Indonesia. This study recommends the government intervention in order to control the cigarette consumptions in Indonesia by pushing the cigarette price and making cigarette less affordable for less rationale smoker (the young and poor people). Secondly, the government can take an action in delimiting the access of cigarette advertising and educate people about the danger of cigarette to the people.
\end{abstract}

Keywords: cigarette consumptions, government policy, rationality of smoker

\section{Introduction}

There are two issues when studying about cigarette industry in Indonesia. On one hand, the government need the excise revenue which has contributed significantly to the national budget. In 2008, the excise revenue was budgeted 45,7 trillion rupiahs or about $1 \%$ of GDP and in 2009, it was budgeted 54,4trillion rupiah or about $1 \%$ of GDP. Yet, on the other hand, it is a health and economic impacts of cigarette consumption in Indonesia. High mortality caused by the disease as the result of consuming cigarette, either direct or indirect, seems to be significant. At 2001 the estimation of death related to tobacco is 427,948 per year and the loss is 7.5 fold to the excise revenue or about $\mathrm{Rp}$ 127trillion. Therefore at 2005 , the estimation is likely to increase to be Rp 154.84trillion or equal to 5 fold of the excise revenue, meanwhile, it was impacted the death of 399,800 people/ year. This study attempts to find the impact of the government policy through the excise tariff policy, and the rationality of the smoker to the cigarette consumption in Indonesia.

\section{Literature Review}

\section{Direct and Indirect Tax Concept}

According to Law No 28 yearly 2007 on General Stipulation and Tax Regulation (Ketentuan Umum dan Tata Cara Perpajakan - KUP), tax is defined as the statutory contribution to the state by individual or corporation, which has 
statutory enforcing power, with no direct return and will be used for state purposes and the citizens prosperous. Boediono (2000) defined a tax as the contribution of the citizen to the state, statutory, enforceable, indirectly return, purposed to finance the government need in order to govern the government and can be used as a medium to govern social-economic aspects.

Generally, the tax is classified on direct and indirect tax. Based on its economic aspect, a direct tax is a tax which its burden cannot be forwarded to other people. For example is income tax. As a reverse, indirect tax is a tax which its burden can be forwarded to other people. The example is excise.

According to Suparmoko (1986) that generally, the indirect tax has several advantages are as follow:

a. As a state revenue source, indirect tax more stable in its yield compared to the result the direct tax;

b. The citizen who has low income who mostly difficult to be imposed by direct tax can be involved to contribute to the state revenue collection which is intended by the government;

c. Low of the imposing cost;

d. Simple in imposing practice thus less tax administrative;

e. Referring to its purposes as one of the regulation means, the indirect taxes can be controlled by the government faster and relatively easy.

However, the indirect tax has disadvantages as well, such as:

a. The tax burden can be shifted to another economic player by both forward shifting as well as backward shifting;

b. As a tool to enhance the production level, the indirect tax cannot or hard to give direct impact to the related industry who has paid the tax.

The above are most common reasons of the developing countries tend to use the indirect tax as the main regular state revenue. But if the purpose of the government is to redistribute the income among the citizens, the direct tax will be more effective. In Indonesia, excise as one of the indirect tax is one of the most preferable among the other indirect taxes.

\section{The Concept of Excise}

The definition of excise as mentioned in Law No 39 yearly 2007 on the amendment of Law No 11 yearly 1995 on excise is the state levy which is imposed on the particular goods which have nature and characteristic, i.e.: its consumption needs to control; its circulation need to supervise; its use ensuing a negative impact to community or environment; and its use needs to impose a state levy in purpose of justice and balance. Excise has a special characteristic which is different to another kind of taxes. And even though categorized as one of the indirect tax, excise still has its specialities. According to Cnossen (1997) those specialities are:

\section{a. Selected coverage}

The selected goods which can be imposed by excise are the goods which are mentioned by the excise law particularly. This is the most problematic in Indonesia case since in the diversification program of the object of excise. In the Law on Excise, the selected goods which are imposed by excise are only for 3 (three) kinds of goods only, even though it is mentioned that in the initial philosophy has been acknowledged on the possibility of diversification of the excised object.

\section{b. Discrimination in its purposes}

Excise is one of the most important indirect tax in several countries mostly in developing countries in terms of its total revenue. Yet, the imposing excise has also other purposes, such as:

a) to control the consumption of particular goods which is beyond the community norms and healthcare, e.g.: cigarette and liquor;

b) to be imposed on luxury goods by concerning its taxpaying capacity;

c) to be imposed on the vehicle as the burden of the use of the road; 
d) to maintain the use of natural sources efficiently;

e) excise on raw material to reduce the waste;

f) to provide employment by imposing high excise to the capital goods which is potentially replacing the human labour;

g) to finance research and trade promotion.

c. Quantitative in the investigation

In the imposing excise, the officer statutorily can conduct a physical supervision to ensure the compliance level of the subjects of the excised goods in this term is the private sectors. The main philosophy of imposing excise according to OECD (2004) is to increase the revenue, to influence the consumer behaviour and utilize the market power to change the consumption pattern. According to that philosophy, most of OECD countries impose the excised goods on three items i.e. liquor, mineral oil and tobacco. In Indonesia, the excised goods consist of three goods which are liquor, ethyl alcohol and tobacco products or cigarette.

\section{Chart 1:}

\section{Classification of Some Important Taxes}

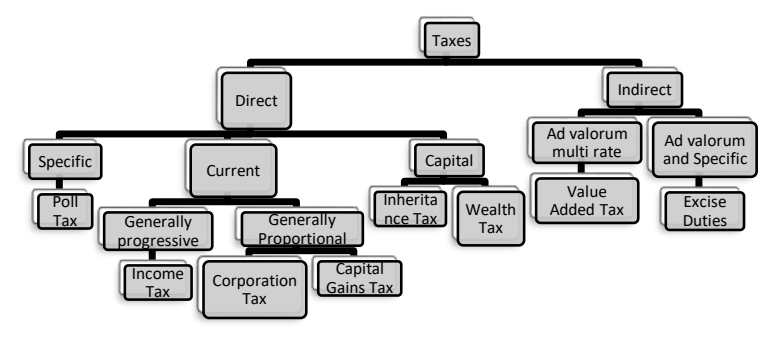

Source: James, S. et. al. (1998).

\section{Advantages and disadvantages of Excise Methods}

According to Yurekli (2006), there are choices in deciding which type of excise is better to the existing economy, specific and Ad Valorem. There are advantages and disadvantages of the types of excise.

\section{a. Specific}

Advantages:
a) Simplicity
- $\quad$ Tax liability easy to measure
- $\quad$ Taxes prepaid on sales

b) Health benefits

- $\quad$ External costs of smoking same for high and low price brands - tax rate should be the same

Disadvantages:

a) Revenues do not increase automatically with inflation

b) Encourages improving "quality" of cigarettes

c) Encourages substitution to (highprice) imported brands; or smuggled-tax free low-quality alternatives

d) Increases potential for tax avoidance and revenue loss if tax base set on characteristic of cigarettes (e.g. weight, content, size of cigarettes)

b. Ad Valorem

Advantages:

a) Tax liability Indexed to cigarette price inflation

b) Discourages substitution from lowpriced to high-priced brands - and so generates higher revenues

c) Discourages investment in advertising to make smoking "glamorous"

Disadvantages:

a) Difficult to collect at retail points of sale

b) Creates potential for tax avoidance and revenue loss

c) Smaller health benefits than equivalent specific tax

\section{Research Method and Design}

Secondary data was obtained from the Directorate General of Customs and Excise, Fiscal Policy Office and Ministry of Finance database. The literature study also applied to establish the relevant theory for the background of study and to meet the relevant regulations and data. 
An analysis based on the econometric model was applied to meet how the consumer's ability to purchase a cigaretterelated to the variability of some variables. This ability to purchase is influenced by several factors such as price, income, taste, advertising etc. In this study, the Rational Models of Addictive Demand approach was applied.

Chaloupka et.al. (1996) devise alternative approaches to economic modelling of the demand for addictive substances on three models i.e. conventional approach, myopic models of addictive and rational models of addictive demand.

The Conventional Approach is a model of the common demand model on a certain period. Myopic can be defined as the short distance vision, therefore the basic of the modelling is the behaviour of the cigarette consumption by minding in the short run. Unlike the conventional demand model, the myopic models of addictive also concerned that the decision to consume cigarette today is as the result of the previous consumption, however when they make their today's decision, they do not mind their consumption in the future. On this model, the previous consumption influenced the current consumption due to the accumulation of the stock of the previous consumption.

This model predicts that the price elasticity of the demand of the cigarette in the long term will be higher than the price elasticity of the cigarette on a short run on the absolute value. The demand of cigarette on the certain period was determined by the current period and the previous period variables

Different from the both models above, in Rational Models of Addictive Demand approach the current demand on a cigarette is determined by factors in the current period, past period and future period.

The model can be depicted as the equation below:

$\mathrm{C}(\mathrm{t})=\mathrm{g}[\mathrm{P}(\mathrm{t}), \mathrm{C}(\mathrm{t}-1), \mathrm{C}(\mathrm{t}+1), \mathrm{Y}(\mathrm{t}), \mathrm{Z}(\mathrm{t})]$

Where:
$\mathrm{C}(\mathrm{t})=$ Cigarette consumption on period $\mathrm{t}$

$\mathrm{P}(\mathrm{t})=$ Current price of cigarette on period $\mathrm{t}$

$\mathrm{C}(\mathrm{t}-1)=$ Cigarette consumption on period $\mathrm{t}-$ 1

$\mathrm{C}(\mathrm{t}+1)=$ Cigarette consumption on period $\mathrm{t}+1$

$\mathrm{Y}(\mathrm{t})=$ income

$\mathrm{Z}(\mathrm{t})=$ vector of variables reflecting tastes

$\varepsilon \mathrm{t}=$ error term

\section{Findings and Analysis}

The data were collected quarterly since 1998 to 2008. Results of the model show that all variables have expected sign except Ads and the adjusted R2 is 0.988007 and positive. Since there is autocorrelation between $\log (\mathrm{C} 1)$ and $\log \left(\mathrm{C}_{2}\right)$, therefore the variable AR was included in the model. In order to diminish the heteroskedasticity, the standard error and variances were treated.

The equation of the demand of cigarette consumption is formulated as follows:

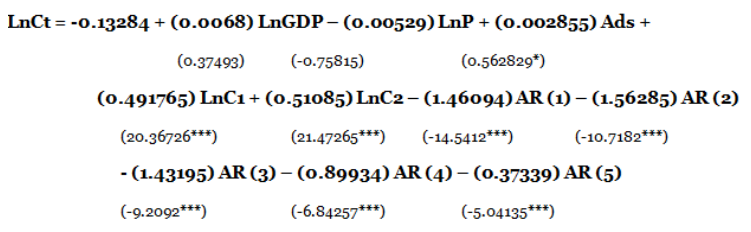

Where:

$\mathrm{C}(\mathrm{t})=$ Cigarette consumption on period $\mathrm{t}$, million sticks

GDP = income, quarterly GDP per capita $(=2000)$

$\mathrm{P}(\mathrm{t})=$ Current price of cigarette on period $t$

Ads = dummy variable on government restriction on cigarette advertising since year 2000,

$\mathrm{O}=$ no restriction, $1=$ with restriction

$\mathrm{C}(1)=$ Cigarette consumption on period $\mathrm{t}-1$, million sticks

$\mathrm{C}(2)$ = Cigarette consumption on period $\mathrm{t}+1$, million sticks

$\operatorname{AR}(\mathrm{t})=\operatorname{lag}(\mathrm{t})$ 


\section{The impact of GDP to Cigarette Consumption}

The regression findings show that GDP has a positive sign and affect consumption. The coefficient of GDP is 0.0068 but has no significances. The interpretation is that GDP improves cigarette consumption by 0.0068 percent in every $1 \%$ increase of GDP by holding other variables constant.

The variable of Income which has positive on the above model is accord to Yurekli (2008) on the year 1970 to 2007 and Djutaharta (2002) on time series year 1970-2001.

From the income elasticity of demand of cigarette, the model resulted in 0.0068 percent, which means that every increase of 10 percent of income will increase the demand by 0.068 percent. This result shows that the increase of income will not give a significant effect on the percentage of the cigarette consumption.

\section{The impact of Price to Cigarette Consumption}

The government policy to control the cigarette consumption can be depicted by imposing excise tariff. In this model, the proxy of the excise tariff is cigarette price. This model applied administered price by the government (minimum selling price) which is stipulated in the Minister Decree.

In this model, the price of cigarette variable has a negative impact on the cigarette consumption, by the increase of the price cigarette by 1 percent, therefore the cigarette consumption will diminish by 0.00529 percent.

Price Elasticity of consumption of the year 1998 to 2008 is 0.00529 which means for every increase in Price by 1 percent will reduce the cigarette consumption by 0.00529 percent. This elasticity is smaller than the result of Yurekli (2008) for 0.3 percent. From the above result, it is showed that the elasticity of price to cigarette consumption in Indonesia relatively low. As the result, it is understood that consumer in Indonesia does not too sensitive to the increase in cigarette price. In 2006, average excise tariff in Indonesia is about $37 \%$ and according to Setyawati (2008) that if excise tariff is less than $65 \%$, therefore, will not so effective in curbing the cigarette consumption.

The phenomenon of high consumption and willingness to pay of cigarette can be seen on its affordability. Based on a study by Adioetomo et. al. (2005), compared to the other ASEAN countries, the cigarette price in Indonesia is relatively lower. The highest price of cigarette in Indonesia is only higher than the Philippine and Vietnam and the lowest price of cigarette in Indonesia is only higher than Cambodia and Laos.

\section{Impact of the Advertising Limitation to the Cigarette Consumption Demand}

In this study, the advertising variable which is used is dummy variable of the government policy by introducing the cigarette advertising regulation. In the model, 1 is employed as the regulation of cigarette advertising limitation was stipulated, and $\mathrm{O}$ is assigned as the cigarette advertising limitation has not been stipulated. The regulation which is the Government Decree No 28 yearly 2000 which is limiting the show time to the cigarette advertising in television, as well as the labelling of the impact of cigarette consumption at the cigarette package.

The result of the model shows unexpected sign which is a positive sign and statistically insignificant. It is inferred that the policy to delimit the cigarette advertising has no impact in reducing the cigarette consumption. The result supports the previous study by and Warner (2000) and Saffer and Chaloupka (2000) that partial bans have little impact on smoking behaviour, given that the tobacco industry can shift its resources from the banned media to those that are not banned.

The above finding can be explained by two reasons:

1. The inconsistency of the advertising limitation policy.

The change in the President of Indonesia impacted in the change to the regulation regarding cigarette. The 
cigarette as the product which has never been touched by the non-tariff regulation was commenced to impose since the political reform in 1999.

In 1999, the new government regulation was imposed with its main rules:

- The maximum tar level i.e. 20 $\mathrm{mg} / \mathrm{stick}$ and Nicotine level of 1.5 $\mathrm{mg} /$ stick as follows:

- Kretek Cigarette - Machine made 2001

- Kretek Cigarette - Handmade (Big Companies) - 2004

- Kretek Cigarette - Handmade (Big Companies) - 2009

- Cigarette advertising was only allowed for printed media and outdoor

- The application of the health warning

Thus, in 2000, as the government was changed by the election, the government rule changed as well. At 2000, the new government rule imposed on several regulations as follows:

- Extend the transition period of the maximum tar and nicotine level:

- White cigarette - 2002

- Kretek Cigarette - Machine made - 2007

- Kretek Cigarette - Handmade 2010

- The advertising on TV was allowed with the time limitation from 21.30pm to $05.00 a m$.

Then, by the change in the government, there was a change in the rule as well.

2. Minimum coverage of the limitation policy.

The decentralization also gave an impact to the regulation on the local government regarding the cigarette. There were several regulations which are stipulated by the local government concerning the cigarette regulations. Those regulations can be mentioned below:

- Local Rule of Jakarta Province No.2/2005 on Air Quality Control on article 13 there was a regulation on no smoking area in the public area

- Government rule No. 75/2005 on Prohibited to smoke Area. This rule concern in the non-smoking area on the public service office.

- Mayor of Surabaya Rule No. 440/2005 on Non-Smoking Area

- Billboard Tax special on Cigarette and Alcohol in Bogor

\section{The impact of Rationality of the smoker to Cigarette Consumption}

The Rational Models of Addictive Demand (Chaloupka et.al. 1996) approach reflects the dependence of current consumption decisions on past behaviour that characterizes the use of an addictive substance and also implies that the future implications of addictive consumption are considered when making current consumption decisions.

The model shows that the rationality of the smoker has a positive sign and significant to the cigarette consumptions. The coefficient of consumption in the previous year is 0.491765 . The interpretation is that consumption in the previous year improves cigarette consumption by 0.491765 percent in every $1 \%$ increase of consumption in the previous year by holding other variables constant. However, the consumption in the next year also gave the same result. The coefficient has a positive sign (expected sign) and significant. By holding other variables remain constant, the increase in the next year consumption by $1 \%$, the current year consumption will increase by 0.51085 percent.

The above results follow Chaloupka et.al. (1996) that: Good is defined as addictive if increase in past consumption raises current consumption, and the future implications of addictive consumption are considered when making current consumption decisions.

There are issues regarding the above findings:

a. The prevalence of smoking 
The result supports the data by the government. Based on data from the economic census by Central Statistics Agency of Indonesia, the prevalence of smoking is increasing. In 1995 there was $53.4 \%$ of a male with age more than 15 years old are a regular smoker and $1.7 \%$ of female are a smoker. The data shows that the trend is higher in 2001 and 2004. In 2001, $62.2 \%$ of a male with age more than 15 years old are a regular smoker or increased by $9 \%$ yet the female regular smoker seems to decline to be $1.3 \%$. However, in 2004, $63.1 \%$ of the adult males are smoking regularly and the high increase in the female regular smoker to be $4.5 \%$. The economic census illustrated that the initial smoking age mostly in the 15 - 19 years old group. In 1995, $54.5 \%$ of the initial smoking group age is $15-19$ years old, meanwhile in 2001 is $58.9 \%$ and in 2004 is $63.7 \%$. The initial smoking age of 15 - 19 years old is increased means that the young smokers are the most targeted of cigarette marketing as they are less informed about the effect of cigarette consumption. Moreover, the young smokers are the targeted of the cigarette marketing due to the potentially long period of cigarette consumption by its addicted content in a cigarette.

b. The poverty and education issue.

The cigarette consumption is likely to be the important expenditure for a family in Indonesia. The tendency to expend more for tobacco is described as follow: In 1995, the cigarette consumption was only taking $6.4 \%$ of the monthly expenditure for the poor, yet in 2005 it was increasing to be $12.5 \%$ of the monthly expenditure. On the other side, the cigarette consumption is only $4.9 \%$ monthly expenditure of the rich and to be $9.7 \%$ in 2004, however, in 2005, it declined to be $9.3 \%$ only. It can be inferred that the cigarette consumption is increased by years or the ability to pay off the family in Indonesia is decreasing. Based on the study by Yurekli (2006), the percentage of the cigarette consumption in several districts in Indonesia in 2006 was higher than the percentage of the consumption of health and education.

The above situation describes how the cigarette consumption can be potentially the problem in health and education for Indonesia in the long run. The lower budget for education and health can reduce the competitiveness of the people of Indonesia.

\section{Policy Implications}

There are issues about the health, poverty and education on cigarette consumption. Therefore, in order to curb the cigarette consumption, the government intervention is needed. The intervention can be imposed by pushing the cigarette price and make cigarette less affordable for the young (less rationale) and poor people.

The other intervention can be conducted by delimiting the access of cigarette advertising and provide a policy to educate people on the hazard of cigarette, mostly to the poor and young. 


\section{References}

Adioetomo, Sri Moertiningsih, Triasih Djutaharta, and Hendratno. (2005). Cigarette Consumption, Taxation and Household Income: Indonesia Case Study. Economics of Tobacco Control Paper No. 26: 1-31.

Barber, Sarah, Sri Moertiningsih Adioetomo, Abdillah Ahsan, and Diahhadi Setyonaluri.(2008).

Ekonomi Tembakau di Indonesia. Depok: Lembaga Demografi: Universitas Indonesia.

Boediono. Perpajakan Indonesia. Jakarta: Diadit Media, 2000.

Chaloupka, Frank J., Grossman, Michael, Tauras, John A.(1996). Public Policy and Youth Smokeless Tobacco Use. National Bureau of Economic Research.

Chaloupka, F. J., \& Warner, K. E. (2000). Chapter 29 The Economics of Smoking. Handbook of Health Economics, 1(PART B), 1539-1627. DOI: 10.1016/S1574-0064(00)80042-6

Cnossen, Sijbren (1983). Comparative Tax Studies: Essays in Honor of Richard Goode" Rotterdam: North-Holland Publishing Company.

Cnossen, Sijbren (1997). Excise System: A Global Study of the Selective Taxation of Goods and Services.Maryland: The John Hopkins University Press.

Government of Jakarta Rule No. 75/2005 on Prohibited Smoking Area.

James, Simon., Nobes, Christopher., the Economics of Taxation: Principles, Policy and Practice, Prentice Hall Europe, 1998, pp. 15.

Law No 28 yearly 2007 on General Stipulation and Tax Regulation (Ketentuan Umum dan Tata Cara Perpajakan - KUP).

Law No 39 yearly 2007 on the amendment of Law No 11 yearly 1995 on Excise.

Local Rule of Jakarta Province No.2/2005 on Air Quality Control.

Mayor of Surabaya Rule No. 440/2005 on Non-Smoking Area.
OECD Tax Policy Studies: Recent Tax Policy Trends and Reforms in OECD Countries. Danvers: OECD Publications, 2004.

Saffer, Henry \& Chaloupka, Frank, 2000. "The effect of tobacco advertising bans on tobacco consumption," Journal of Health Economics, Elsevier, vol. 19(6), pages 1117-1137, November.

Setyawati, Sri U. (2008). http://www.hukumonline.com/berita/b aca/hol19979/cukai-tinggi-dapatbatasi-konsumsi-rokok. Last accessed 20 May 2010.

Suparmoko. Keuangan Negara dalam Teori dan Praktek. Yogyakarta: BPFE, 1986.

Yurekli, Ayda. 2006. Design and Administer Tobacco Taxes. World Bank Economics of Tobacco Toolkit. 